PROJECT GNOME DECONTAMINATION

AND DECOMMISSIONING PLAN

ERRATA

Replace paragraph D-2 with the following:

2. VI. C. 4. The criteria for the cleanup of unusual surface variances of $>15 \mu R / h$ has been changed to $>20 \mu R / h$ above background. This change resulted from experience gained in excavations made in cesium contaminated areas in May 1979, when it was noted that, in general, $\mu-R$ instrument readings on surfaces of less than 25 $\mu-R$ were cif soils that were less than soil criteria $\left(2 \times 10^{-5} \mu-\mathrm{Ci} / \mathrm{g}\right)$.

Replace Section $F$ with the following:

F. Return of site to BLM

The Department of Interior, BLM, has stated that LRL-7, and DD-1 may be utilized as long term monitoring holes. They have further requested the following actions take place prior to the return of the site to BLM:

1. Remove small building.

2. Leave pump in USGS-1.

3. Leave electric poles from the access terminal to the operational areas.

4. Leave fence and roads.

5. Leave the caliche pit to the east of Section 34 as is.

6. Leave the plastic lined pit at USGS-1 as is.

These requests will be honored. 


\section{DISCLAIMER}

This report was prepared as an account of work sponsored by an agency of the United States Government. Neither the United States Government nor any agency Thereof, nor any of their employees, makes any warranty, express or implied, or assumes any legal liability or responsibility for the accuracy, completeness, or usefulness of any information, apparatus, product, or process disclosed, or represents that its use would not infringe privately owned rights. Reference herein to any specific commercial product, process, or service by trade name, trademark, manufacturer, or otherwise does not necessarily constitute or imply its endorsement, recommendation, or favoring by the United States Government or any agency thereof. The views and opinions of authors expressed herein do not necessarily state or reflect those of the United States Government or any agency thereof. 


\section{DISCLAIMER}

Portions of this document may be illegible in electronic image products. Images are produced from the best available original document. 
This document is the operational plan for conducting the final decontamination and decommissioning work at the site of the first U.S. nuclear detonation designed specifically for peaceful purposes and the first underground event on the Plowshare Program to take place outside the Nevada Test Site. The plan includes decontamination and decommissioning procedures, radiological guidelines, and the NV concept of operations. 
TABLE OF CONTENTS

PROJECT GNOME DECONTAMINATION AND

DECOMMISSIONING PLAN

Title

$\underline{\text { Page }}$

I. INTRODUCTION

A. General

B. Background

C. Objectives

1

1

6

$\begin{array}{ll}\text { II. SITE STATUS } & 7\end{array}$

A. General 7

B. Surface Facilities 7

C. Unplugged Monitoring Holes 7

D. Security and Classification $\quad 8$

E. Surveillance Program 8

III. RADIOLOGICAL SURVEYS 9

IV. ORGANIZATIONAL MANAGEMENT CONCEPT 10

A. Department of Energy, Nevada Operations Office (DOE/NV) 10

B. Fenix \& Scisson, Inc. (F\&S) 11

C. Reynolds Electrical \& Engineering Co., Inc. (REECo) 11

V. GENERALIZED SITE ACTIVITIES AND LOGISTICS 12

A. Trailers 12

B. Power 12

C. Communications 12

D. Construction Water 12

E. Vehicles 12

F. Occupational Health and Safety 13

G. Site Maintenance $\quad 14$

VI. RADIOLOGICAL SUPPORT PLAN 14

A. Purpose 14

B. Operational Radiological Safety 14

C. Operational Program $\quad 15$

D. Radiation Monitoring 17

E. Radioactive Materials Consideration 17

F. Environmental Sampling 18

$\begin{array}{lll}\text { VII. ENVIRONMENTAL IMPACT ASSESSMENT } & 18\end{array}$ 
VIII. DECONTAMINATION/DECOMMISSIONING OPERATIONS

A. Hole USGS-1 19

B. Hole LRL-7 20

C. Hole SR-2A $\quad 21$

D. Miscellaneous Site Restoration 23

E. Crushing and Slurry Facility : . 23

F. Plugging of Related Holes $\quad 24$

IX. PUBLIC INFORMATION AND OPEN FILES 25

A. News Announcements 27

B. Briefings and Meetings $\quad 27$

C. Open Files 27

X. REPORTS 27

$\begin{array}{ll}\text { A. F\&S } & 27\end{array}$

B. REECo 28 
PROJECT GNOME

I)ECONTAMINATION AND DECOMMISSIONING PLAN

I. INTRODUCTION

A. General

Project GNOME was the first nuclear detonation designed specifically for peaceful purposses and the first underground event on the Plowshare Program to take place outside the Nevada Test Site. The objectives were as follows: (1) to determine the phenomenology of a nuclear explosion in salt; (2) to determine the recoverability of isotopes from a salt medium, including device products and special isotope additions; (3) to determine the recoverability of heat from a nuclear explosion in salt; (4) to perform severall neutron physics experiments; and (5) to obtain information useful in the design of future Plowshare events.

The GNOME site is located in Eddy County, in southeastern New Mexico (Figure 1), about 50 road kilometers ( 31 miles) southeast of Carlsbad, New Mexico. The sinaft head is in the center of Section 34, Township 23 South, Range 30 East, New Mexico Principal Meridian, at an elevation of 1,039 meters (3,408 feet) above mean sea level.

B. Background

As part of the Plowshare Program, the AEC (subsequent1y ERDA, now DOE) approved plans for a small nuclear shot in a salt formation in June 1958. On October 20, 1958, the GNOME site was selected. Authorization was granted to proceed with the construction of facilities on March 16, 1960. The emplacement facility consisted of a vertical shaft 10 feet in diameter by 1,216 feet leep and a lateral drift (tunnel) which averaged 8 feet by 10 feet and extended to the northeast 1,116 feet, terminating in a buttonhook configuration at the working point.

Application for withdrawal of the required 680 acres (emplacement site and control point areas) was submitted to the U.S. Bureau of Land Management by the Albuquerque Operations office on April 6, 1960. Approval for this withdrawal was authorized by the Department of Interior on October 21 , 1969, via Public Land Order (PLO) 2526. In addition to the land withdrawal, rights-of-way for access roads, power lines, seismic cable, sites for a radio relay tower, and some test wells were acquired by various land use agreements.

Project GNOME was detonated on December 10, 1961, with a nuclear yield of 3.1 kilotons. The detonation caused a cavity 80 feet in radius and 72 feet high, producing a total cavity void volume of about 960,700 cubic feet (see Figure 2).

Project GNOME postshot reentry activities were completed in June 1962 , and limited activities were commenced for Project $\mathrm{COACH}$ during late 


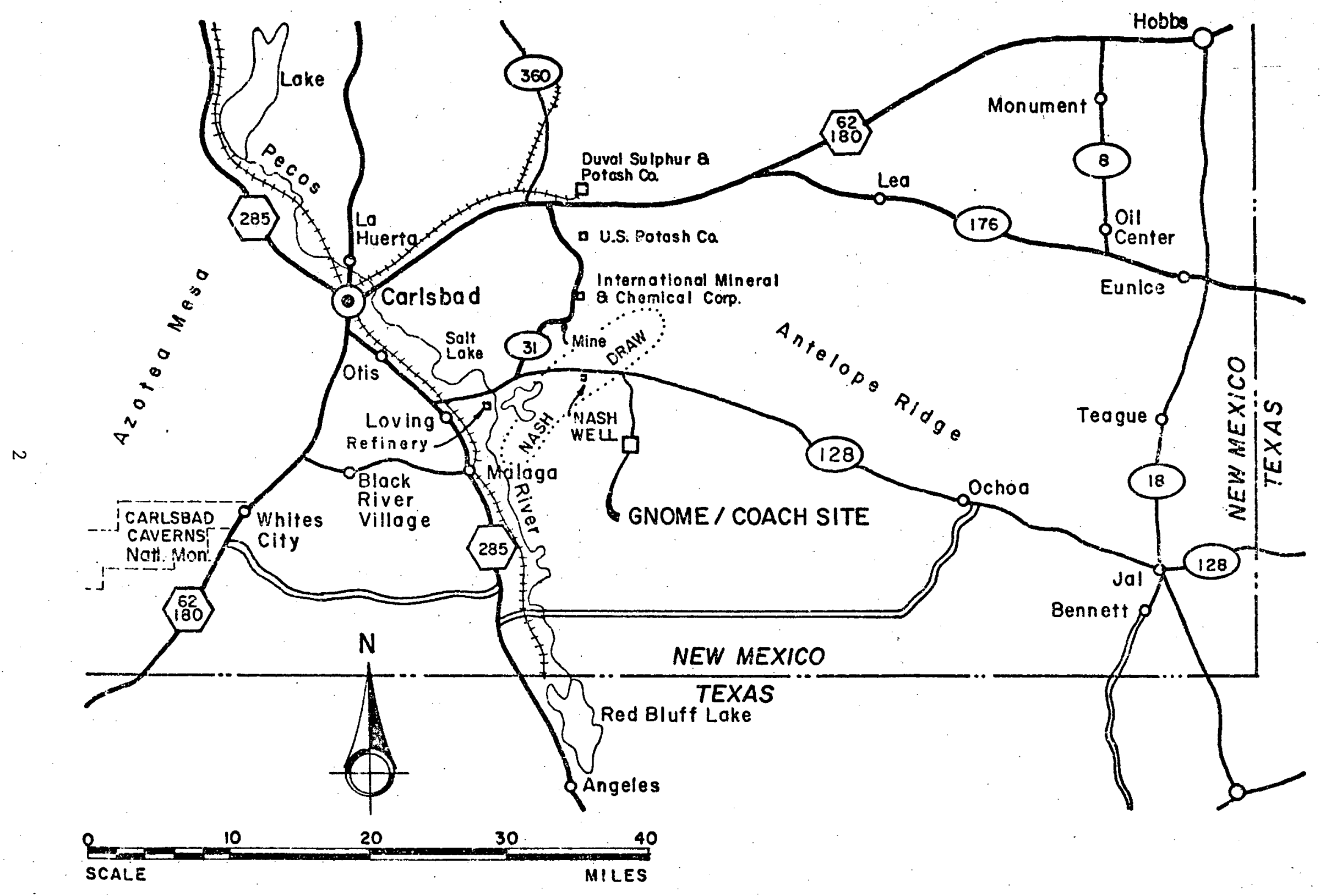

FIGURE 1 Carlstad Area and Grome/Coach Site 


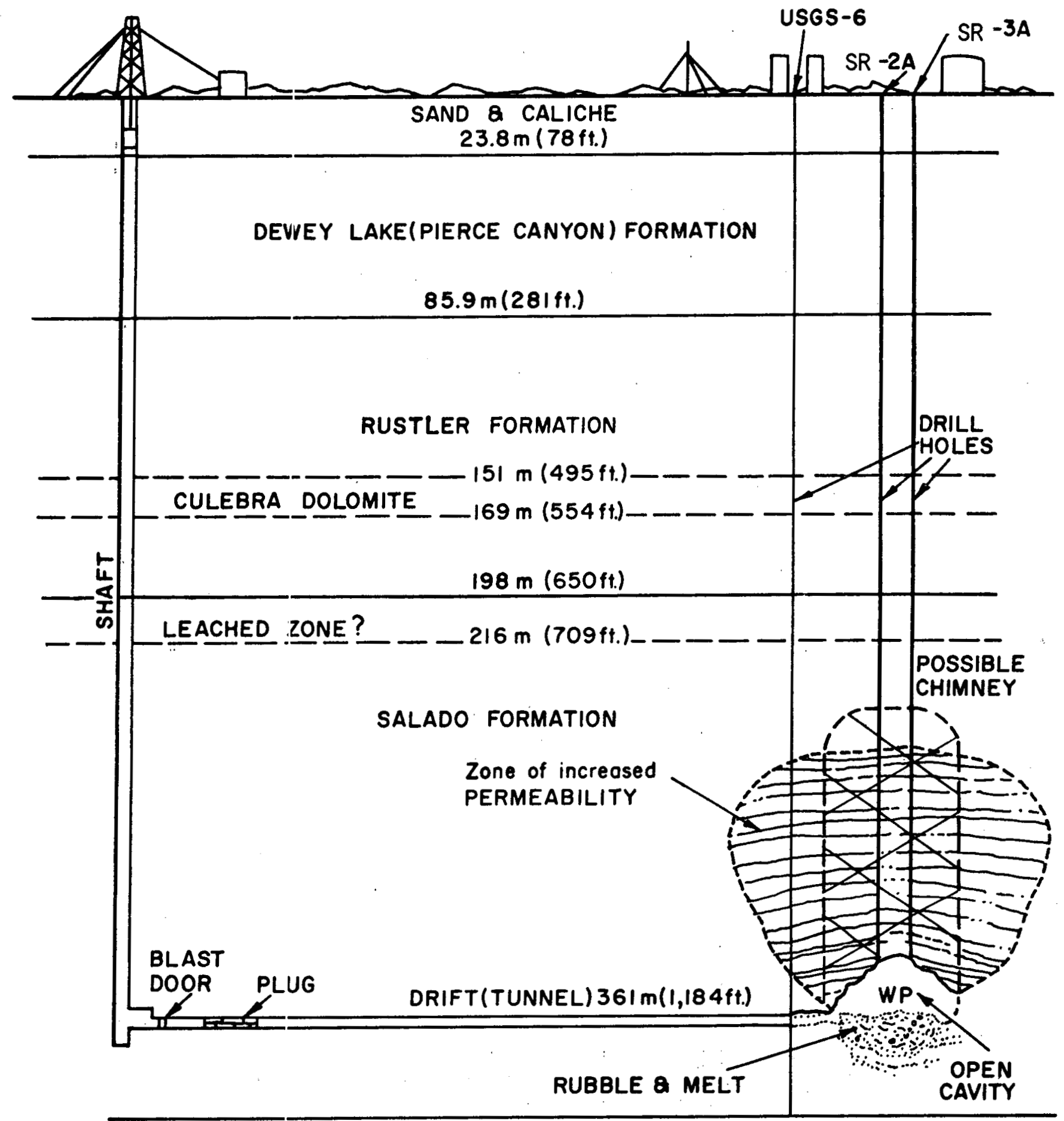

FIGURE 2 Section Through the Gnome Event Site 
CY 1962 and early CY 1963. The COACH objectives were: (a) to produce, recover, and identify sma11 quantities of new transuranium radionuclides and possibly new heavy elements; and (b) to produce and recover relatively large quantities of certain known transuranium elements of interest.

The limited construction activities for Project $\mathrm{COACH}$ included: (a) rehabilitating the Project GNOME shaft and extending its depth to 1,284 feet; (b) constructing a 12-foot-wide by 10-foot-high drift (at the 1,284-foot level) extending southeast 1,130 feet, where it narrowed to 7 feet and continued 630 feet, where a 6-foot-wide by 9-foot-high reverse drift extended upward at a 30-degree angle for 185 feet to the ground zero room; and (c) drilling four holes from the surface to the Project $\mathrm{COACH}$ drift (see Figure 3). After several delays, Project $\mathrm{COACH}$ (initially scheduled for February or March 1963 execution) was canceled because of difficulties in explosive development and changes in program emphasis.

The site remained in standby status until March 1968. During 1967, NV began planning for site disposal and determined that there were no further requirements for the site within the AEC. In March 1968, the Atomic Energy Commission/Division of Peaceful Nuclear Explosions (AEC/DPNE) requested preparations for ultimate disposal of the site. In the period June through December 1968, contaminated equipment and all materials and facilities were removed and disposed of, in accordance with AEC criteria for surface radiological contamination (REECo Report NV0-410-2, July 1969). In the first half of 1969, final cleanup and plugging of all drill holes except those retained for monitoring by USGS were completed in accordance with the then established criteria.

Upon approval by DPNE on February 6, 1970, the "Notice of Intent" to return the site to the BLM was prepared and, on July 1, 1970, accepted by Harold A. Berends, Chief, Branch of Lands/BLM, Santa Fe, New Mexico. The official publication in the Congressional Register never took place, however.

On February 10, 1972, the Roswell BLM office stated that it required additional information before it would accept accountability and responsibility for the Project GNOME site. In short, the BLM wanted to know if there were hazards to the public at the site and if so, the nature and extent of needed restrictions for the site.

During May 1972, on a routine survey of the site, small quantities of unexploded dynamite sticks and blasting caps were found to have weathered to the surface of the salt muck pile. Several areas, including the salt muck pile, gave radioactive levels up to $5 \mathrm{mrad} / \mathrm{hr}$, with one location reading $45 \mathrm{mrad} / \mathrm{hr}$.

The Manager, NV, on April 12, 1972, informed the Roswell BLM office of a possible hazardous condition and requested a temporary suspension of any action to return the 1 and to public use.

During June 1972, after an exchange of messages between the Division of Military Applications (DMA) and NV, the General Manager/AEC HQ requested 


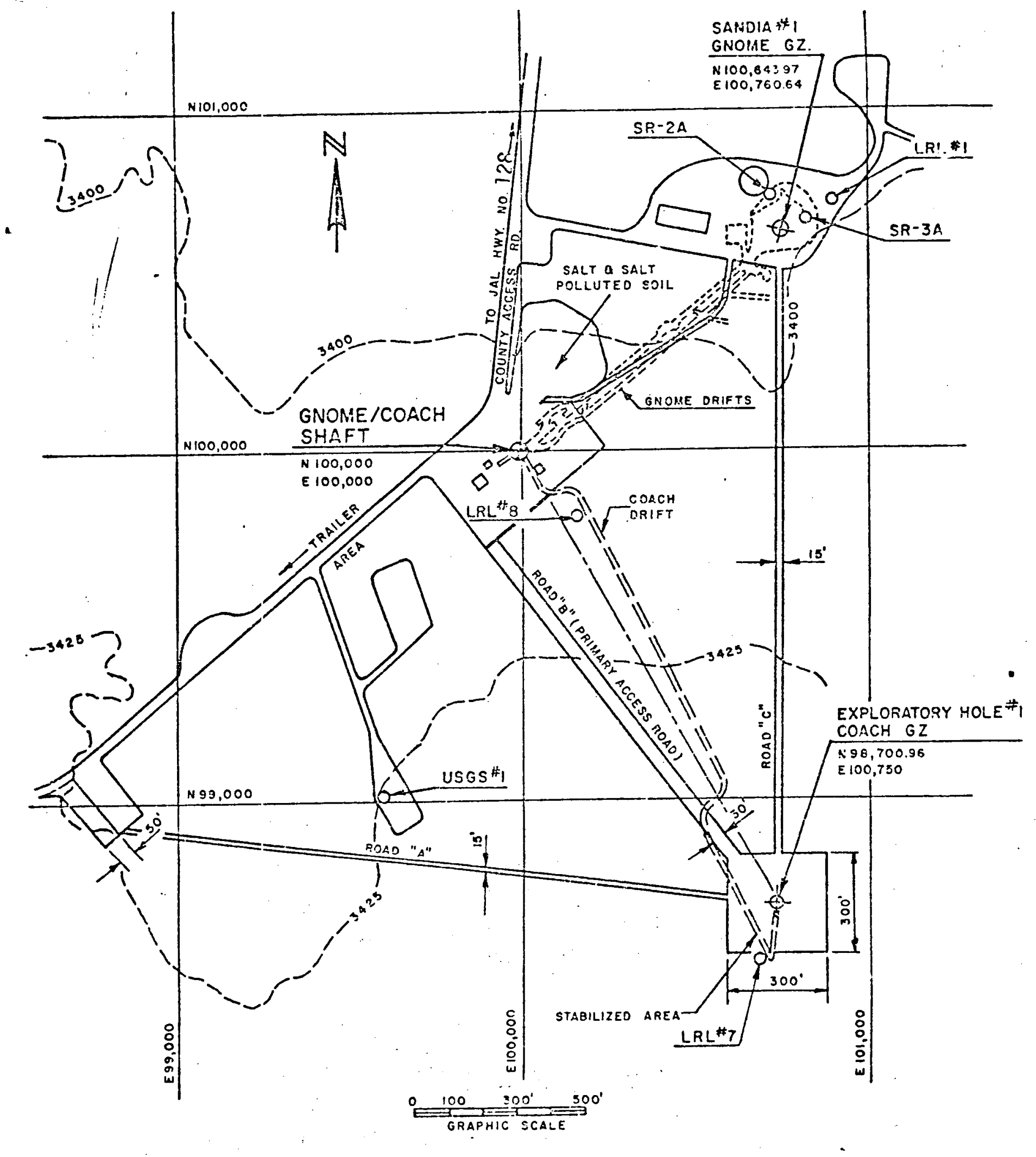

FIGURE 3 Project Gnome/Coach Site Plan 
cost estimates to resurvey the GNOME site and develop an appropriate cleanup plan.

On November 15, 1972, NV submitted a letter to the General Manager/AEC HQ recommending actions leading to the disposal of the site. A detailed radiation survey proposal by REECo was attached. It was recommended that the site remain in minimal caretaker status until funds could be identified for: (1) performing the detailed radiological survey, (2) preparing detailed engineering plans for disposal options of the salt muck pile, and (3) conducting comprehensive site cleanup actions.

During the period from 1973 to 1977 , routine visits were made to the site to reconfirm the public safety and environmental conditions on and near the site and to assess routine maintenance. In July 1977, the Environmental Control Technology (ECT) directed NV to initiate work on the Decontamination/Decommissioning (D/D) of the Project GNOME test site. NV developed a plan for the decommissioning program which called for the work to be done in three phases:

Phase I--Aerial and Ground Survey

Phase II--Cleanout of Holes

Phase III--Area-wide Cleanup

The first part of Phase I, identified as Phase IA, was started on August 1 , 1977, and completed on September 30, 1977. (REECo report "GNOME Site Decontamination and Decommissioning--Phase IA," dated December 1977.) Phase IB, which completed Phase I, was conducted from March 1, 1978, through FY 1978. The final report and findings were submitted in December 1978. (NVO/0410-48, "GNOME Site Decontamination and Decommissioning-Phase I.")

Concurrent with the initiation of the survey, DOE granted Sandia approval to drill an Exploratory Hydrological Test hole (ERDA No. 10) at the GNOME site in order to obtain fault features and water content above, in, and below the Salado formation. ERDA No. 10 was one of several test holes drilled in the area during a feasibility study in relation to long-term storage of radioactive waste material in the Salado salt. The hole was spudded in the $\mathrm{N} \mathrm{1/2}$, NW 1/4, NW 1/4, NE 1/4 of Section 34. An 18-inch hole was drilled to 40 feet and $133 / 8$-inch casing was set to 37 feet and cemented to the surface. A 12 1/4-inch hole was drilled to 905 feet and a 7 7/8-inch hole was drilled from 805 feet to 4,431.5 feet. The hole was plugged with cement from total depth to the surface on October 14 , 1977.

C. Objectives

The overall program objective is to decontaminate and decommission the Carlsbad (GNOME/COACH) site which will enable the DOE to release the area to the custody of the Department of Interior, BLM. The release will have no restrictions other than the establishment of an annual hydrologic survey to reconfirm public safety with respect to the possible migration. of the contaminated material sealed in the cavity and a restriction on drilling or mining near the contaminated zone. Accordingly, prior to the demobilization of $D / D$ activities, a joint inspection of the GNOME site will be made by a DOE/NV and BLM representative. DOE will initiate 
actions to return the site to BLM following the joint inspection and BLM concurrence.

The restoration of the GNOME/COACH land to the public domain will be made in accordance with DOE Manual Chapter 5301.

\section{SITE STATUS}

\section{A. Genera1}

The site encompasses approximately 680 acres and is described as follows: New Mexico Principal Meridian, Township 23 South, Range 30 East, Section 10, NW $1 / 4$ of the NW 1/4, 40 acres, and all of Section 34,640 acres (see Figure 3). Withdrawal of the land from public domain was authorized by Public Land Order (PLO) 2526 on October 26, 1961, by the Department of the Interior. Custody and responsibility for the land belongs to DOE.

\section{B. Surface Facilities}

1. A barbed wire fence around Section 34 with locked gates and "prohibited entry" signs posted.

2. A five-foot-high hog wire fence topped with barbed wire around the muck pile. This fence is posted with warning signs to keep the public off the surface of the muck pile.

3. One small concrete block building (now substantially razed through vandalism).

4. Terminus of a $69 \mathrm{KV}$ electrical transmission line constructed and owned by the Southwest Public Service Commission. This was left in place at the suggestion of the BLM.

5. A county access road leading to Highway 128. Primary access roads $\mathrm{A}, \mathrm{B}$, and $\mathrm{C}$, connecting the trailer area, $\mathrm{COACH} \mathrm{GZ}$ area, GNOME GZ area, and the GNOME/COACH shaft area. Secondary roads providing access to drill holes (USGS 1,4 , and 8 ).

6. Various concrete pads which provided the foundation for the buildings and work areas.

7. A concrete monument located at the GNOME surface ground zero with two bronze plates describing the GNOME event and the restriction placed on excavation and/or drilling.

8. A 350-foot by 350-foot, caliche-covered drill pad is located in the $\mathrm{N} 1 / 2$ of the NW $1 / 4$ of the NW $1 / 4$ of the $\mathrm{NE} \cdot 1 / 4$ of Section 34 .

\section{Unplugged Monitoring Holes}

The holes listed below have been capped and padlocked. Responsibility for these holes has been transferred, in writing, to the USGS with the approval of the New Mexico State authorities. 
1. USGS No. 1, N99,007, E99,606, with 12 3/4-inch casing set at 577 feet and cemented to the surface. A 12-inch-diameter open hole extends to a total depth of 728 feet.

2. USGS No. 4, N100,394, E97,625, with 8 5/8-inch casing set at 473 feet and cemented to the surface. A 7 5/8-inch-diameter open hole extends to a total depth of 518 feet.

3. USGS No. 8, N100,394, E97,500, with 8 5/8-inch casing set at 460 feet and cemented to the surface. A 6 1/4-inch-diameter open hole extends to a total depth of 721 feet.

\section{Security and Classification}

There is no classified contaminated particulate matter or other debris on or at the surface of the GNOME/COACH site. It is not anticipated that any of the work required at the site will change this condition. However, in the unlikely event that classified material is brought to the surface, it will be placed under the custody of a "Q" access authorized person until it can be disposed of by returning downhole or shipment off site.

E. Surveillance Program

\section{General}

DOE has been visiting the Project GNOME site on a periodic basis in order to reconfirm the public safety and environmental conditions existing on or near the site. Biweekly patrols of the site are currently being made by a locally hired caretaker. These patrols will end following final decontamination/decommissioning activities and return of the site to BLM.

\section{Hydrology}

In accordance with NV's policy, a long-term hydrologic monitoring program has been established for the GNOME/COACH site. This program was developed by the NV staff with the assistance and concurrence of the Scientific Manager for Geology and Hydrology, Desert Research Institute, Teledyne Isotopes, EPA Environmental Monitoring Support Laboratory (EMSL), and the USGS. The NV Hydrologic Program Advisory Group has endorsed this program and recommended its initiation; accordingly, EPA/EMSL was authorized to initiate the program on February 3, 1972. This program will continue indefinitely.

\section{a. Sample Network}

The following sampling points were selected to sample water from all water-bearing strata in the area down hydraulic gradient from surface ground zero: 
(1) Municipal Supplies

Carlsbad City Well--7

Loving City We11--2

Malaga City Tap Water

(2) We11s

USGS- 1 USGS- 8 PHS-8 PHS -10

USGS- 4 PHS 6 PHS-9

(3) Surface

Pecos River Pumping Station

b. Analyses

Unless otherwise specified, all samples will continue to be collected and analyzed annually for tritium, using low-level techriques, All samples are analyzed for gross alpha, gross beta, and a gamma spectral scan. Gross chemical analyses, comparable to the USGS chemical water quality analyses, were perfcrmed on all samples collected on the initial sample run. After the initial run, only samples from the Malaga City well are chemically analyzed. Based on the results of these analyses, suspect samples are analyzed for appropriate naturally occurring and nian-made isotopes. Splits of each sample collected are retajned as long as a need exists for this purpose. If a meanjngful increase in radionuclide concentration occurs, the Office of Safety and Health and the Radiological Branch, NV, are to be notified immediately.

\section{RADIOLOGICAL SURVEYS}

Reynolds Electrical \& Engineering Co., Inc. (REECo), implemented a comprehensive radiological survey in 1977 to assist in the development of the operational plan for the final decontamination and decommissioning of the site. This survey was conducted in two parts. Phase IA was initiated August 1, 1977, and completed September 30, 1977. It included: (1) In situ Gamma Survey, (2) Aerial Survey, (3) Grid Layout, (4) Auger Proof Test, and (5) a Metal Detector Survey. EG\&G performed the aerial and in situ survey, while REECo conducted the remainder of the: on-site activities. Phase IB commenced March 1, 1978, and was terminated at the end of FY 1978. It consisted of: (1) Radiological Survey and (2) Evaluation of Proposed Guidelines. The total survey effort and results are defjned in detail in NVO/0410-48. This report also presents the associated analytical data, mathematical modeling, and pathway analysis.

The result of the survey: showed that the doses calculated using the existing site data would not pose a radiological hazard from cesium-137, strontium-90, or tritium. It was, therefore, concluded that the proposed guidelines of 20 $\mathrm{pCi} / \mathrm{g}$ of beta-gamma emitters could be used for the GNOME site decontamination and decommissioning. By disposing of the salt muck pile and the known areas 
of radioactive concern, the site average will, in fact, be reduced to approximately $4.6 \mathrm{pCi} / \mathrm{g}$, which is well below the proposed guideline.

\section{ORGANIZATION AND MANAGEMENT CONCEPT}

A. Department of Energy, Nevada Operations Office (DOE/NV)

1. The DOE, through the Manager, NV, will appoint a DOE Project Director who will have the overall responsibility for the achievement of all project objectives. The major areas of responsibility are as follows:

a. Provide a project plan.

b. Execute necessary contractual arrangements with REECo and F\&S for decontamination and radiological safety programs and logistical support.

c. Develop cost estimates for project approval and identify cost reporting practices and controls to be effective during the period of project execution.

d. Execute the approved field operation, assuring effective program liaison with the HQ Division of Environmental Control Technology and other interested parties; provide an NV Project Engineer who will be responsible for the day-to-day, on-site direction of project effort.

e. Review and certify the provisions for safety of on- and off-site personnel and for minimizing the accidental damage or loss of. equipment, materials, and property. Provide and interpret radiological control and documentation criteria. Radiological operations will be supervised by an NV Radiological Operations Supervisor (ROS).

f. Approve all major changes to the plan.

g. Manage and coordinate F\&S, REECo, and DOE on-site activities.

2. The Project Director will be represented on site by individuals with the following designations and responsibilities:

a. Project Engineer: The Project Engineer will be responsible for day-to-day general project direction, including coordination of the $F \& S$ and REECo interface. The Project Engineer will make project execution decisions within the prescribed limits of authority, as required, to expedite project accomplishment. The Project Engineer will keep the Project Director advised of the daily work status and will maintain an up-to-date project cost record.

b. Radiological Operations Supervisor (ROS): The ROS will be responsible for assuring that the Radiological Support Plan is 
in accordance with project requirements and current DOE radiological criteria. The ROS will be cognizant of radiological conditions and will assist in the initial on-site coordination of the F\&S/REECo interface and follow the day-to-day operations of the radiological support contractor.

B. Fenix \& Scisson, Inc. (F\&S)

1. Fenix \& Scisson, Inc., as prime contractor under contract to DOE/NV, will provide the materials, services, and technical direction required to accomplish the $\mathrm{D} / \mathrm{D}$ operation, except for those services associated with radiological support. In the exercise of the above, F\&S will appoint a Project Manager with the following major areas of responsibility.

a. Prepare a detailed operational program plan.

b. Execute subcontracts to provide the labor, equipment, and materials support necessary to accomplish the work described in Section VIII and provide on-site supervision for the work. This work includes the rehabilitation of roads and the mobilization of equipment, the performance of the actual cleanup operation, well plugging and abandonment, and site restoration activities.

c. Coordinate, as necessary, with the radiological support contractor, REECo, to ensure timely, safe, and cost-effective operations.

d. Provide advice to DOE and REECo regarding procedures for the most economic method of project accomplishment.

e. Suspend site activities and initiate emergency procedures if any operation jeopardizes personnel or property.

f. Provide daily work progress and weekly cost reports to the DOE Project Engineer and provide assistance, as required, to evaluate the cost and schedule impact of plan changes prior to their implementation.

g. Provide a final report summarizing the cleanup operation, well abandonment, and site restoration activities.

C. Reynolds Electrical \& Engineering Co., Inc. (REECo)

REECo, as the radiological support contractor under contract to $\mathrm{DOE} / \mathrm{NV}$, will provide technical direction and on-site supervision to accomplish al1 radiological decontamination work in accordance with DOE radiological criteria. REECo will report to the Project Manager through the ROS. Major responsibilities are as follows:

1. Provide radiation detection capability appropriate to the nature of the contaminant and its possible dispersion. 
2. Provide radiological surveillance, monitoring, and analyses and maintain appropriate records.

3. Control site access to the operational areas and provide dosimetry.

4. Provide personnel and equipment decontamination capability.

5. Coordinate radiological activities, as necessary, with the efforts of $F \& S$ in order to achieve safe, economic, and timely operations.

6. Keep the NV ROS and/or the Project Engineer continually advised of radiological conditions and provide a daily work progress report.

7. Maintain a weekly cost status report and assist the Project Engineer in projecting and estimating the impact of approved program changes.

8. Complete a Radioactive Material Shipping Record for all radioactive shipments.

9. Provide a Supplementary Radiation Contamination Clearance Report to NV upon completion of field operations. This report will subsequently be submitted to HQ.

\section{GENERALIZED SITE ACTIVITIES AND LOGISTICS}

A. Trailers

Two government trailers will be furnished through REECo for on-site activities. One trailer will be equipped for sample preparation and storage of miscellaneous supplies. The other trailer will be equipped for sample radioactivity analysis. F\&S will provide one office trailer (locally rented) with desks and chairs for administrative use.

B. Power

REECo will furnish one $6.5 \mathrm{KW}$ generator. F\&S will make provisions for bringing utility-generated power on site.

c. Communications

REECo Communications will provide on-site walkie-talkies for field communication. F\&S will furnish two mobile phone units in the office trailer.

D. Construction Water

F\&S will supply water for the slurry.

\section{E. Vehicles}

Project organizations will be responsible for providing and maintaining their own vehicles. 
F. Occupational Health and Safety

1. Genera1

Al1 operations and activities will be conducted in accordance with the standar:ds of the Occupational Safety and Health Act of 1970 (OSHA).

A11 participating organizations are responsible for the health and safety of their own personnel and for conducting all activities in accordance with procedures that assure:

a. A safe and healthful environment for the employees.

b. Control and minimization of hazards to the public and to personnel or: other participants.

c. Minimization of the accidental damage or loss of equipment, materials, and property.

d. Compliance with on-site radiological safety procedures.

2. Medical Se:rvices

a. F\&S w:L11 make arrangements for emergency medical care.

b. F\&S will provide two physician-approved first aid kits to be located in the office trailer.

3. Fire Proteition

F\&S will sıpply one hand-held fire extinguisher at each trailer location. Extinguishers will be the universal type for control of Class A, B: or C fires.

4. Radiologicial Protection

REECo will provide personnel radiological safety services as described in the Radiological Support Plan.

5. Potable Water

F\&S will picovide potable water containers and bottled water.

6. Sanitation

F\&S will p:covide two chemical toilets, which will be serviced on a weekly schedule. 


\section{G. Site Maintenance}

F\&S will provide generalized site maintenance such as trash removal and general policing of the work areas.

\section{RADIOLOGICAL SUPPORT PLAN}

The DOE/REECo radiological evaluation (Phase 1) of the GNOME site has established conditions and a logical basis for the completion of the proposed decontamination and decommissioning.

\section{A. Purpose}

These procedures consider the unknown radiological conditions that may exist either in the contaminated salt muck pile or within the presently sealed GNOME cavity. They also define the DOE/NV radiological requirements, which include:

1. Documentation of radiological conditions at the GNOME cleanup operation.

2. Minimizing radiation exposure to participants and the public.

3. Accurate and rapid analytical capability for radiological conditions.

4. Complete decontamination of a11 GNOME site areas in excess of DOE/NVproposed criteria.

5. Supplementary Radiation Contamination Clearance Report.

REECo Environmental Sciences Department (ESD) is the DOE/NV prime contractor and will implement the above requirements.

\section{B. Operational Radiological Safety}

During each operational phase, i.e., drillback, cavity ventilation, crusher, other heavy equipment operations, transporting muck or soil, and other activities at the GNOME site which require operating personnel, ESD will provide:

1. A radiation detection capability appropriate to the nature of the contaminant and its possible dispersion.

2. Controlled access, maintaining a log of all persons potentially exposed or within a controlled area.*

* The area of control and its delineation will depend on operational and meteorological conditions and will be jointly established by the DOE/NV ROS and the ESD Site Supervisor (SS). 
3. Dosimetry, as may be necessary to establish ALARA control or zero exposure data. For personnel:

a. Gamma dosimetry (TLD or film) will be provided to and worn by al1 project personnel during the operational period of the cleanup. At the conclusion of the project, all personnel dosimetry data (external exposure and bioassay) will be included in the REECo Master Dosimetry File.

b. Bioassay.. Urine specimens will be collected and analyzed from participating project personnel, but not from visitors or temforary participants who are known not to have received an external or internal exposure. One urine specimen will be collected and analyzed at time of arrival, and again upon permanent departure from the site, unless operational conditions dictate a greater frequency.

4. Soil, air, and water sampling and analysis for tritium and gamma qualitative/quantitive analysis (for cesium or other fission products) will be c.vailable for use at GNOME as required by the ROS. This includes a complete analytical capability in the form of proportional counters, tritium scintillation analysis, and a gamma spectrometry capability.

5. Portable instrumentation for detection of alpha, beta/gamma, or low-level. gamma will be available for use as needed.

6. A personrel and equipment decontamination capability.

7. Radiologj.cal monitoring and shipping records.

C. Operational Program

Phases II and III of the GNOME Site D/D will be conducted in a single operation.

1. USGS Wel1. 1--Water Supply

The rehatilitation of the USGS Well 1 will not require direct radiological support; however, no potentially contaminated equipment is to be used for rehabilitation of this hole.

2. Phase II--Cleanout of $S R-2 A$ and $L R L-7$

a. Cleanout and opening of the GNOME reentry hole SR-2A and LRL-7. Isolation of radioactive materials from these drillbacks will require that a "decontamination holding area" be established. Conversely, a "clean hold area" will also be designated. A reletase $\log$ will be maintained at the reentry rig, describing each major item or group, and identifying its radiological conclition. 
All solids or liquids from the reentry operation will be contained until a determination of their radiological status and proper disposal can be determined.

b.: Decontamination Holding Area

A welded steel pan, 45" $x, 12^{\prime}$, having an integral 400-gallon sump will be installed within the holding area and set on an appropriate slope to provide drainage for the hot water decon system.

If contaminated equipment or materials are incurred during the drillbacks or decontamination operations, they will be immediately isolated, disposed of, or decontaminated. This procedure will avoid cross-contamination or contamination of soil in the area. The dimensions and location of the decontamination holding area will be as designated by the ROS and the SS. Contaminated materials or equipment will not be placed in contact with the soil.

Gaseous effluents of either SR-2A or LRL-7 will be filtered (with respect to tritium oxide) prior to atmospheric release.

Radiological surveillance will continue until each hole is plugged at completion of operations.

3. Phase III--Decontamination Operations

Disposal and Slurry Plant Operation will have continuous gamma monitoring (continuously recorded) of all material introduced into the GNOME cavity. All ripping, dumping, shoveling, crushing, and conveying operations generating a visible atmospheric dust-loading will have the following radiological support and requirements:

a. Downwind air monitoring to document air quality. Filters will be changed for analysis on a four-hour basis or removed for radioanalytical measurements at the end of the operation.

b. Personnel are required to wear dust respirators.

c. Anticontamination clothing, i.e., booties, gloves, and coveralls, will be provided when designated by either the ROS or the SS.

\section{Site Soil Removal Procedure}

Several small areas and volumes of earth where soil analysis has indicated an elevated ( $2 \times 10^{-5} \mu \mathrm{Ci} / \mathrm{g}$ averaged over $1 / 4$ hectare) concentration or a discernible ( $>15 \mu \mathrm{R} / \mathrm{h}$ above background) reading (see report number NVO/0410/48) will be excavated and removed for disposal within the GNOME cavity. This operation will be conducted under the supervision of cognizant radiological personnel familiar with the Phase I evaluation. 
Assays to verify the adequacy of the decontamination procedures will be performed on site and within 24 hours of the sample collection.

D. Radiation Monitoring

1. Specific responsibilities of the GNOME site monitor will be as follows:

a. Monitor, using instruments and swiping methods, the radiological condition of drilling equipment as disassembly is accomplished.

b. Contain all contaminated fluids and solids as they are produced.

c. Provide proper anticontamination and protective respiratory equipment, if required, for site personnel.

d. Provide necessary containment for equipment during handling between the drilling location and the decontamination area.

e. Halt work if the radiological condition would cause unacceptable contamination of the site or operating personnel.

f. Survey closed equipment for explosive mixtures, as required.

g. During cleanout operations, monitor circulation, fluids and solids, tubing, piping, and rig for radioactive contamination. Take gas samples prior to any venting to determine radiological conditions. Vent all gases through appropriate filters.

h. Report any radioactive reading above background to the ROS/NV and Project Engineer at once.

i. Maintain daily operations $\log$, recording events as they occur in chronological order.

j. Equipment and material other than DOE property, when released to unrestricted use, will be placed in a "clean" holding area for disposition.

\section{E. Radioactive Materials Consideration}

\section{Drilling Circulation Fluids}

All circulation fluids will be contained and frequently monitored for beta-gamma emissions with a portable gamma instrument. Grab samples will be taken every four hours at the discharge line into the containment tank and analyzed for tritium and gamma on site. If results indicate the presence of radionuclides not naturally occurring, further analyses may be required. If an unlikely abnormality is discovered, the ROS will be consulted and operational direction developed (see letter of Radiological Considerations for Project GNOME Decontamination and Decommissioning, August 24, 1977). 
2. Combustible waste having no contamination can be burned on site consistent with the State of New Mexico requirements.

3. Items of materials and equipment or waste not released to unrestricted use will be shipped to an approved disposal site. Packaging and shipment will be in accordance with Department of Transportation (DOT) regulations.

4. Alpha contamination is not present at the GNOME site other than in natural radioactivity. Alpha measurements will not be taken routinely.

5. Gas samples will be taken of any pressure venting which is expected to release more than a cubic meter of gas. All gas releases will be vented through filters.

\section{F. Environmental Sampling}

1. Additional environmental samples of surface and subsurface materials will be taken as requested by the Ros to provide additional site documentation, or as necessary to support the Supplementary Radiation Contamination Clearance Report.

\section{Water Sampling}

The only surface water on site that could be contaminated is that which will result from decontamination. This water will be flushed into the GNOME cavity. Water from USGS Well 1 will be sampled and analyzed for tritium.

\section{I. ENVIRONMENTAL IMPACT ASSESSMENT}

An environmental assessment was prepared in accordance with procedures defined in ERDA-IAD No. 0510-5, dated January 26, 1977, which prescribes the procedures to be followed for implementing the National Environmental Policy Act of 1969. The purpose of this assessment was to present a brief description of the proposed activity for the GNOME site abandonment and its potential impacts on the environment. It is the determination of the assessment that the requested action does not constitute a major federal action significantly affecting the environment in the sense of the National Environmental Policy Act of 1969, Section 102(2)(C).

This assessment is available from the Engineering and Energy Applications Division, Nevada Operations Office, of the U.S. Department of Energy, Las Vegas, Nevada 89114.

\section{D/D OPERATIONS}

A description of the required primary activities at the GNOME/COACH site is as follows: 
A. Hole USGS 1--Present Conditions

1. Location: Sec. 34, T23S, R30E, Eddy County, New Mexico (N 99007', E $\left.99606^{\prime}\right)$.

2. Ground level elevation: $\pm 3,425$ feet.

3. Type of hole: water monitoring and supply well.

4. Casing: $123 / 4^{\prime \prime}$ O.D. casing set with bottom at $577^{\prime}$.

5. Open hole: A 12-foot hole was drilled from 577 feet to a total depth of 728 feet. The hole was plugged back with cement from 728 feet to 56,7 feet and casing perforated between 518 feet and 550 feet. A lock cap was installed on the top of the 12 3/4-inch casing.

Program

1. Rig up mast truck and electric line logging truck. Run a fluid probe to cletermine the static fluid level and tag plug back depth. This should be done prior to moving in a rig to determine what depth the submer:sible pump should be designed for. Also run an 11- to 12-inch gauge ring on wireline to plug back depth. This will establish that there are no obstructions in the casing or sand in the open hole.

2. Move rig on location, raise derrick, and hook up anchor and guy lines.

3. Remove look and cap from 12 3/4-inch 0.D. casing and install a tubing heid to support the tubing and downhole pumping equipment.

4. Run a Reda, Centrilift, or equivalent, submersible pump. Pump suction expected to be positioned \pm 560 feet. Pump will be run on 2 7/8-inch 0.D., 6.5 \#/ft., K-55, EUE 8rd tubing.

5. Hang the tubing off and hook up pump. Install necessary transformers, switchboard, and junction box. A 480-volt line will be run to supply po'ser for the pump.

6. Test pump for a required period to establish its working order and also the rates at which fluid can be removed from the hole without lowering the water level to the pump suction. Hole productivity expected to be $\pm 100 \mathrm{GPM}$ ( $\pm 3,428 \mathrm{bbl} /$ day):

\section{Construction}

1. Excavate a water storage pit. Dimensions: $75^{\prime} \times 100^{\prime} \times 6^{\prime}$ (capacity: $45,000 \mathrm{ft}^{3}, 8,021 \mathrm{bbl}$.). Insta11 a pit liner of $\pm 10,000 \mathrm{ft}^{3}$ of 20 mil PVC. 
2. Lay a water supply line $\pm 2,000$ feet from USGS 1 storage pit to location of crusher plant on the north side of the salt muck pile. Water line is to be 4-inch $0 . D$. nominal thread and coupled pipe or PVC. Installation to be done by roustabout-type labor crews.

3. Install a centrifugal pump at the storage pit and hook up to water line. Pump shall be capable of pumping at a rate of $400 \mathrm{GPM}$ at a discharge pressure of 55 psi (approximately 17 input horsepower assuming a 70 percent pump efficiency).

\section{Notes:}

1. Construction work outlined above can be done at the same time the pump is being installed in USGS 1 .

2. All depths referred to above are from ground level.

B. Hole LRL-7--Present Conditions

1. Location: Sec. 34, T23S, R30E, Eddy County, New Mexico (N 98540', E $100700^{\prime}$ ).

2. Ground level elevation: 3,443 feet.

3. Type of hole: Cable hole into COACH drift.

4. Casing: $133 / 8$-inch O.D. casing set at 788 feet in a.17 1/2-inch hole and cemented to surface.

5. A 12 1/4-inch hole was drilled from 788 feet to the COACH drift at 1,314 feet.

6. A bridge plug is set inside the 13 3/8-inch $0 . D$. casing at 760 feet and the casing is plugged with cement from 760 feet to surface.

7. The 13 3/8-inch 0.D. casing is cut off at ground level.

\section{Program}

1. Move on location, raise derrick, and hook up anchor and guy lines.

2. Insta11 slip-on and weld 13 3/8-inch casing head and 12-inch, 2,000\# or 3,000 作 rotating head with a flanged outlet.

3. Pick up and rig up power swivel. Hook up piping for circulating in reverse.

4. Pick up a 12 1/4-inch rock bit with nozzles removed. Drill out 13 3/8-inch casing from surface to top of bridge plug at 760 feet using reverse circulation with gel-water. Drill bridge plug. The drill string will consist of nine $61 / 4-i n c h$ O.D. $x 21 / 2$-inch I.D. drill collars and 3 1/2-inch 0.D., 13.3 \#/ft., Grade "E" drill pipe. 
Weight on the bit should be 15,000 非 with rotary speeds of $80-128 \mathrm{rpm}$. Gel-water will drip out of the hole into the drift when bridge plug is drilled.

5. Continue down the hole with the 12 1/4-inch bit and clean out any debris inside $121 / 4$-inch open hole from 788 feet to the top of the COACH driet at 1,314 feet. Pull out of hole laying down 3 1/2-inch $0 . D$. drill pipe and drill collars.

6. Run the stereo camera and inspect the condition of the COACH drift.

7. Remove rotating head from 13 3/8-inch casing head. Install any Rad-Safe Eiltering equipment if so required. This hole will be used as a breather hole during the disposal of the salt muck pile slurry down Hole SR-2A.

8. Rig down and move rig off location.

\section{Notes:}

1. A screen system will be installed over the return pit and cement cuttings : $525 \mathrm{ft}^{3}$ (111 barrels) will be collected and later injected into the avity with the salt muck pile.

2. All depths referred to above are from ground level.

C. Hole SR-2A--Present Conditions

1. Location: Sec. 34, T23S, R30E, Eddy County, New Mexico (N 100649', E100742').

2. Ground level elevation: 3,397 feet.

3. Type of hole: Postshot reentry into GNOME cavity.

4. Casing: $133 / 8$-inch 0. D. casing is set in a $171 / 2$-inch hole at 530 feet and semented to surface. $103 / 4-i n c h$ O.D. casing is set from 22 feet to 843 feet and cemented from top to bottom in a 12 1/4-inch hole. $75 / 8$-inch O.D. liner is hung uncemented in a $97 / 8$-inch hole from 820 Eeet to'1,137 feet, hariging 2 feet into the GNOME cavity.

5. A wooden bridge plug is set inside the 10 3/4-inch O.D. casing at the top of the $75 / 8$-inch liner at 820 feet. Four sacks of $8-12$ sand and two sacks of Ca1-Seal were placed on top of the wooden plug and hole cemented back to surface with $445 \mathrm{ft}^{3}$.

6. The $133 / 3$-inch $0 . D$. casing was cut off at ground leve1.

\section{Program}

1. It will bie necessary to locate the SR-2A casing using a backhoe. Casing ha:s been cut off below ground level. Move on location, raise derrick, and hook up anchor and guy lines. 
2. Install slip-on and weld $103 / 4-$ or $133 / 8$-inch casing head and 12or 10 -inch rotating head with flanged outlet.

3. Pick up and rig up power swivel set up for circulating in reverse.

4. Pick up 12 1/4-inch rock bit with nozzles removed. Drill out 13 3/8inch casing from surface to the top of the $103 / 4$-inch casing at 22 feet using reverse circulation with gel-water. Care must be taken not to damage the top of the $103 / 4$-inch casing. Pull out of hole and lay down 12 1/4-inch bit.

5. Pick up a $97 / 8$-inch rock bit with nozzles removed and dril1 out cement from inside $103 / 4-i n c h$. D. casing using reverse circulation with gel-water. Drill string will consist of nine $61 / 4-$ inch $0 . \mathrm{D} . \mathrm{x}$ 2 1/2-inch I.D. drill collars and 3 1/2-inch 0.D., 13.3 非/ft., Grade "E" drill pipe. Weight on the bit should be 15,000非 with rotary speeds of $100-150 \mathrm{rpm}$. There is a wooden bridge plug at 820 feet with \pm 8 feet of $8-12$ sand on top of it. Drill the wooden bridge plug and clean out the $103 / 4-i n c h 0 . D$. casing to the top of the 7 5/8-inch 0.D. 1iner at 820 feet. Care must be taken not to damage the top of the 7 5/8-inch 0.D. 1iner. Gel-water will drop out of the hole into the cavity when bridge plug is drilled. Rad-safe will provide for monitoring of any cavity gases at the surface.

6. Pick up a $65 / 8$-inch or $61 / 2$-inch rock bit and make a bit run inside of the $75 / 8$-inch 0.D. liner to 1,137 feet. The $75 / 8$-inch $0 . D$. casing is set with the bottom at 1,137 feet hanging 2 feet into the GNOME cavity. Rotate and drill out any debris encountered inside the 7 5/8-inch $0 . D$. liner. The 6 1/4-inch $0 . \mathrm{D}$. drill collars should be laid down before making the $65 / 8$-inch bit trip. Caution must be exercised if debris is encountered inside the $75 / 8$-inch liner. Rotation must be kept at a minimum because the liner is uncemented.

7. Pull out of hole laying down 3 1/2-inch drill pipe and remove rotating head.

8. Run the stereo camera and inspect the cavity and rubble pile, as directed by DOE representative. Run additional logs if required. If a water level can be seen with the camera, a water sample will be taken.

9. Rig up handling tools, using casing crew run $\pm 1,140$ feet of $51 / 2-$ inch 0.D., 14.0 非 ft: or 15.5 \#l/ft., K-55, LT\&C casing bottom joint mule shoed. Install 12- x $51 / 2-$ inch slip and seal assembly and hang $51 / 2$-inch $0 . D$. casing. Install 6 -inch gate valve and bolt down plate around seal assembly.

10. Rig up two 750 CFM (250 psi) air compressors to 6-inch gate valve. Inject air into cavity to determine if there is communication with the cavity and LRL-7. Injected air is to be metered and volumes recorded on IADC report. 
11. Rig down and move rig off location. Surface piping for receipt of salt muck slurry can be made.

\section{Notes:}

1. A screen system will be installed over the return pit and cement cuttings $\pm 430 \mathrm{ft}^{3}$ (76 barrels) will be collected and later returned to the cavity with the salt muck pile.

2. All depths referred to above are from ground level.

3. Step 4 calls for a $121 / 4$-inch bit to drill out the top 22 feet of the $133 / 8$-inch $0 . D$. casing. If the disposition of the $103 / 4$-inch $0 . D$. casing is such that it can easily be tied back to the surface, this will be done instead of nippling up on the $133 / 8$-inch $0 . D$. casing.

D. Miscellaneous Site Restoration

Labor crews and equipment will be contracted to perform the following:

1. Repair approximately four miles of boundary fence.

2. Fill all excavations, grade, and reshape all disturbed areas.

3. Barrel any contaminated trash which will then be transported to the Nevada Test Site.

4. Mobilize and demobilize equipment associated with the crusher plant and slurry mixing system.

5. Remove and replace monument.

6. Rehab roads and locations as required.

7. Remove zertain identified scrap metal from operational areas and restore these areas.

8. Remove any nonpermanent buildings and/or structures as required.

9. Install a metal cattle guard at the north entrance to the GNOME site.

E. Crushing and Slurry Facility

1. A crushing piant will be set up on the north side of salt muck pile. The crusher will be capable of reducing the solids to a size which can be nixed with gel-water to form a pumpable slurry. Crushing equipment will be designed to deliver \pm 75 tons of 1/4-inch-size materiall per hour. 
2. A system of mud tanks equipped with jet-type mixing nozzles will be set up. Storage facilities for bulk bentonite using air pressure for transfer will be installed.

3. The gel-water will be mixed and then combined with the crushed salt muck pile to form a slurry.

4. A centrifugal pump will be used to pump the salt muck pile slurry from mixing pits into the $S R-2 A$ hole.

5. It may be necessary to screen and recycle some of the muck pile to the crusher in order to obtain the proper particle size.

6. Solids to be mixed into a slurry will be transferred from the crusher to the mixing pits by conveyor. Continuous operations will be maintained by alternating mixing and pumping pits.

7. Water supply will be from 4-inch O.D. line laid from the USGS 1 storage pit.

8. The contents of the salt muck pile will be broken up by a dozer with ripping equipment, gathered, and transferred to the crushing facility by front-end loaders.

F. Plugging of Related Holes

\section{1. $\mathrm{SR}-2 \mathrm{~A}--\operatorname{Program}$}

a. Move on location, raise derrick, and hook up anchor and guy Iines.

b. Pull 5 1/2-inch 0. D. casing and lay down same.

c. Rig up electric line unit and run gauge ring inside $103 / 4$-inch 0. . casing to 120 feet. Run and set a bridge plug inside of $103 / 4$-inch casing to \pm 800 feet.

d. Run in with 2 7/8-inch O.D., 6.5 \#/ft., K-55, 8rd thread tubing to top of bridge plug and plug hole back with cement from top of bridge plug to surface. Volume of cement required is 450 $\mathrm{ft}^{3}$. Use Class "A" Neat cement mixed at 15.6 \#/gallon with fresh water.

e. Remove all wellhead equipment and cut casing off at ground level. Install 4-inch O.D. steel pipe hole marker extending four feet above ground level if so required. Place hole marker into unset cement.

f. Rig down and move rig off location. 
2. LRL-7--Program

a. Move on location, raise derrick, and hook up anchor and guy lines.

b. Rig up electric line unit and run gauge ring inside 13 3/8inch 0.D. casing to 770 feet. Run and set a bridge plug inside of $133 / 8$-inch casing to 760 feet.

c. Run in with 2 7/8-inch O.D., 6.5 \#/ft., K-55, 8rd, thread tubing to top of bridge plug and plug hole back with cement from top of bridge plug to surface. Volume of cement required is $625 \mathrm{ft}^{3}$. Use Class "A" Neat cement mixed at 15.6 \#/gallon with fresh water.

d. Remove all wellhead equipment and cut casing off at ground level. Install 4-inch 0.D. steel pipe hole marker extending four feet above ground level if so required. Place hole marker in to unset cement.

e. Rig down and move rig off location.

3. USGS 1--Program

a. Prior to moving the rig on location, disconnect power to pump. Remove switchboard, transformer, and junction box. Remove 3-inch flow line to storage pit.

b. Move rig on location, raise derrick, and hook up anchor and guy lines.

c. Pick up a joint of 2 7/8-inch 0.D., 8rd, 6.5 \#/ft. tubing and tie into pump tubing. Unbolt and remove top of tubing support head. Pull pump from hole removing and spooling cables.

d. After pump has been removed, reinstall cap and lock on 12 3/4inch casing. Rig down and move the rig off location.

e. Roustabouts will remove plastic liner from storage pit and dirt contractor will backfill and contour pit area.

f. The USGS 1 hole will be left open for monitoring purposes. The schedule for the final D/D operation is depicted in Figure 4. IX. PUBLIC INFORMATION AND OPEN FILES

\section{Genera1}

For general policy guidance, the following will apply to the Project GNOME $D / D$ operation: 


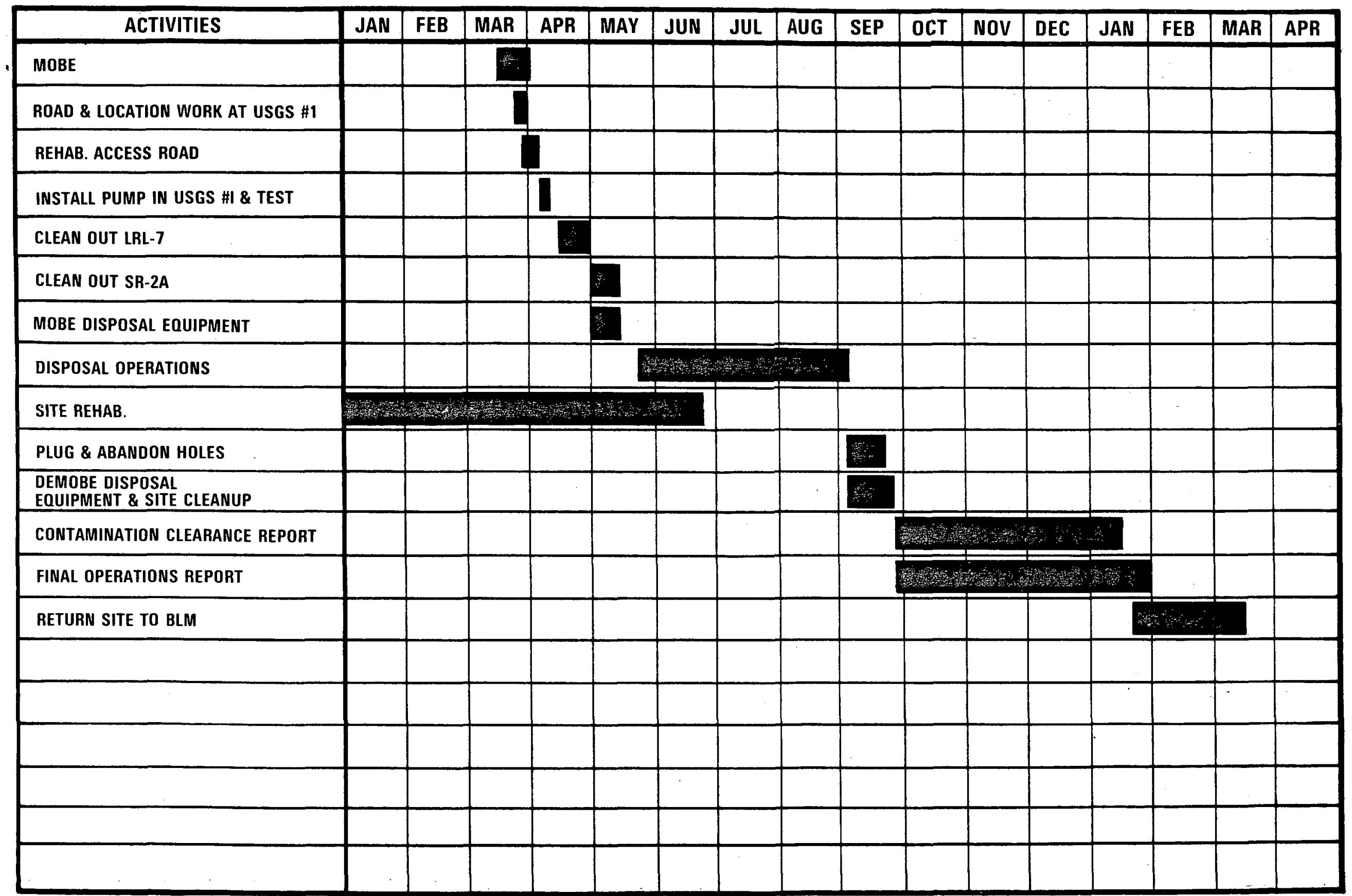

\section{FIGURE 4 PROJECT GNOME}


A. News Announcements

1. A comprehensive public announcement was released on August 5, 1977, regarding the initiation of survey work to prepare for $D / D$ of the GNOME site. No adverse public comment was noted.

2. All accidents and incidents of consequence will be reported to the NV office of Public Affairs, which will report them publicly as soon as possible.

B. Briefings and Meetings

1. State officials were informed prior to the first public announcement with a cover letter including the public announcement.

2. Individual newsmen and officials should be escorted to the site on request and briefed by on-site personnel whenever possible.

3. Personnel of this office met with and advised the New Mexico Environmental Improvement Division and the Roswell District of the Department of Interior, BLM, of the proposed cleanup in January 1979. Both agencies expressed agreement with the D/D plan. BLM stated that they would reaccept custody of the land and keep it fenced and in a wilderness condition for future studies.

C. Open Files

Upon completion of the site decommissioning and decontamination operations, all final reports will be placed in the GNOME open files.

X. REPORTS

F\&S and REECo will submit periodic and final reports as identified below:

A. F\&S

1. Daily Work Progress Report

An infornal report will be submitted to the Project Engineer at the end of each workday. The report will consist of a handwritten summary aarrative of the cleanup operations and general support work. The report will contain information pertinent to the field operations of that day.

2. Week1y. Cost Status

This report will include all costs incurred during the preceding workweek and will be submitted to the Project Engineer on the first work day following the reporting week: 
3. Fina1 Report

This report will summarize all $\mathrm{D} / \mathrm{D}$ activities and record the site status at project conclusion. Included will be the final disposition of all materials and equipment.

B. REECO

1. Daily Work Progress Report

An informal report will be submitted to the Project Engineer through the ROS at the end of each work day. The report will consist of a handwritten summary narrative of radiological operations for that day. Significant progress made or major problems encountered should be highlighted.

2. Weekly Cost Status Report

This report will include field costs and laboratory support costs incurred for radiological work during the preceding work week. The report will be submitted to the Project Engineer within three weeks following the reporting week.

3. Radioactive Material Shipping Record (NV-152)

This form will be completed for all radioactive shipments from the GNOME site.

4. Supplementary Radiation Contamination Clearance Report

This report will summarize all site restoration radiological activities, describe final site radiological conditions, and contain other information as required by DOEM Appendix 5301. The draft report will be submitted to NV for review within 60 days of the end of field operations. 
APPENDIX A

DISTRIBUTION LIST

Maj. Gen. J. K. Beatton, MA/HQ (DP-20)

Sheldon Meyers, OlNWM/HQ (ET-90)

G. H. Daly, ONWM/HQ (ET-90)

R. C. Clusen, ASE/HQ (EV-1)

W. E. Mott, ECE/HA (EV-50) (2 cys)

A. F. Kluk, ECE/HQ $(E V-52)$

K. R. Baker, OEC/liQ (EV-733) (2 cys)

USDOE, TIC (UC-70 Distribution), Oak Ridge, TN (27 cys)

D. T. Schueler, Al,O

C. D. Broyles, SL, Albuquerque, NM

G. E. Tucker, SL, Albuquerque, NM

Robert Statler, Sl, Albuquerque, NM

J. C. Hopkins, LAisL, Los Alamos, NM

J. E. Dummer, LAS], Los Alamos, NM

J. S. Kahn, LLL, livermore, CA

John Toman, LLL, Jivermore, CA

K. M. Oswald, LLL, Mercury, NV

James $0^{\prime}$ Conner, UisDOI-BLM, Roswe11, NM

Technical Library, FC/DNA, Kirtland AFB, NM

T. A. Wolff, Manager, Radiation Protection Section, State of

New Mexico, Sani:a Fe, NM

G. B. Morgan, EPA'EMSL, Las Vegas, NV

H. F. Mueller, WSINSO/NOAA, Las Vegas, NV

Zolin Burson, EG\&(', Las Vegas, NV

Librarian, EG\&G, luas Vegas, NV (2 cys)

M. E. Gates/T. E. Wade, Manager's Office, NV

P. J. Mudra, Director, Operations Support Division, NV

J. B. Cotter, Director, Engineering \& Energy Application Division (6 cys)

D. G. Jackson, Dilector, Office of Public Affairs, NV

P. B. Dunaway, Dilector, Transuranics Office, NV

E. M. Douthett, Director, Physical \& Life Science Division, NV

T. H. Blankenship, Director, Safeguards \& Security Division, NV

B. W. Church, Radiation Branch/OSD, NV

J. R. Boland, Radiation Branch/OSD, NV (20. cys)

R. R. Loux, Office Public Affairs, NV

Technical Library; NV (2 cys) 
Department of Energy

\section{RECEIVED BY TIC JUL 181979}

Nevada Operations Office

P. O. Box 14100

Las Vegas, NV 89114

Nh13 13

Those on the Attached List

PROJECT GNOME DI:CONTAMINATION AND DECOMMISSIONING PLAN (NVO-202)

Attached please find a copy of Addendum $A$ to identify

required change:; from the Project Gnome Decontamination and Decommissioning Plan (NVO-202).

\section{E\&EAD:RDC-1181}

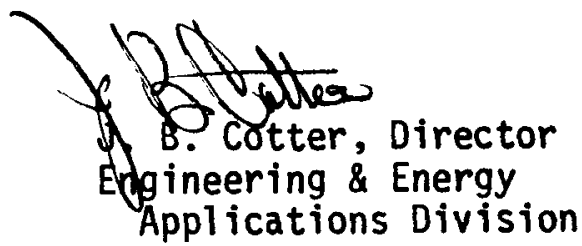

Enclosure:

As stated 
APPENDIX A

DISTRIBUTION LIST

Maj. Gen. J. K. Bratton, MA/HQ (DP-20)

Sheldon Meyers, OlNWM/HQ (ET-90)

G. H. Daly, ONWM/HQ (ET-90)

R. C. Clusen, ASE، HQ (EV-1)

W. E. Mott, ECE/HA (EV-50) (2 cys)

A. F. Kluk, ECE/HQ (EV-52)

K. R. Baker, OEC/HQ (EV-733) (2 cys)

USDOE, TIC (UC-70 Distribution), Oak Ridge, TN (27 cys)

D. T. Schueler, AlsO

C. D. Broyles, SL, Albuquerque, NM

G. E. Tucker, SL, Albuquerque, NM

Robert Statler, Sl, Albuquerque, NM

J. C. Hopkins, LAisL, Los Alamos, NM

J. E. Dummer, LAS], Los Alamos, NM

J. S. Kahn, LLL, J,ivermore, CA

John Toman, LLL, ]ivermore, CA

K. M. Oswald, LLL, Mercury, NV

James O'Conner, UisDOI-BLM, Roswe11, NM

Technical Library, FC/DNA, Kirtland AFB, NM

T. A. Wolff, Manager, Radiation Protection Section, State of

New Mexico, Sant:a Fe, NM

G. B. Morgan, EPA'EMSL, Las Vegas, NV

H. F. Mueller, WSiso/NOAA, Las Vegas, NV

Zolin Burson, EG\&(, Las Vegas, NV

Librarian, EG\&G, las Vegas, NV (2 cys)

M. E. Gates/T. E. Wade, Manager's Office, NV

P. J. Mudra, Director, Operations Support Division, NV

J. B. Cotter, Director, Engineering \& Energy Application Division (6 cys)

D. G. Jackson, Dilector, Office of Public Affairs, NV

P. B. Dunaway, Director, Transuranics office, NV

E. M. Douthett, Director, Physical \& Life Science Division, NV

T. H. Blankenship: Director, Safeguards \& Security Division, NV

B. W. Church, Radjation Branch/OSD, NV

J. R. Boland, Radjation Branch/OSD, NV (20 cys)

R. R. Loux, Office Public Affairs, NV

Technica1 Library: NV (2 cys)

A. Bicker, REECo, NTS, NV ( 4 cys)

J. Cross, F\&S, Las; Vegas, NV (4 cys) 


\title{
PROJECT GNOME \\ DECONTAMINATION AND DECOMMISSIONING PLAN
}

\author{
ADDENDUM A
}

\section{A. Purpose}

The purpose of Addendum $A$ is to identify required changes from the Project Gnome Decontamination and Decommissioning Plan (NVO-202). The basic change in the operation is the recycling of fluid from the cavity tunne1 complex by pumping it back to the surface from Hole LRL-7 (or other access, if necessary) through a pipeline and storage tank system to be discharged back into the cavity as the lubricant for additional salt and soil.

The changes are necessitated as a result of cavity fill-up with soil, salt, and water which reached the shoe of the SR-2A casing (depth 1,137 feet below ground leve1) on June 30, 1979. An immediate reentry of SR-3A commenced, but at a depth of 708 feet, a metal obstacle was encountered. Consequently, the decision was made to drill a new hole into the apex of the zavity at a depth of 1,104 feet.

B. Background

NVO-202 describes general and specific details related to the field operation required to decontaminate and decommission the GNOME/COACH site near Carlsbal, New Mexico. The objectives of the plan require: (1) a comprehensive radiological survey of the site area, (2) the establishment of estimated quantities of soil that need to be excavated from site work areas, (3) an evaluation of the salt muck pile and the delineation of the zone of contamination both within and beneath the pile that would require excavation and disposal, and (4) the release of the area to the Department of Interior, BLM, for unrestricted public use.

The estimated quantities of soil established by the radiological survey, the quantity of salt in the muck pile which contained the additional hazard of dylnamite remnants and blasting caps, and the amount of water required to Lubricate and transport salt and soil solids into the cavity for final disposition dictate the need for careful and prudent control procedures with flexibility to alter the downhole slurrying disposal method if neisessary. There is not, nor has there ever been, any certainty that the cavity can ultimately accommodate all the material.

\section{Status}

From the mid--May 1979 commencement of the downhole slurrying operation through June 30, 1979, several variations in the operation were necessitated due to the nature of the materials. A plant was erected consisting of a series of three crusher units and seven conveyor belts for transport of the materials to a hopper where they were mixed with fresh water for maximum dissolution of the salt during transport through a sloping line 
(approximately 320 feet) into tubing running downhole into the GNOME cavity. Of the two existing plugged and abandoned holes into the cavity (designated $: 3 R-2 A$ and $S R-3 A$ ), $S R-2 A$ was selected for the first reentry, although neither hole entered the cavity at its high point. The selection of SR-2A pernitted the future use of SR-3A for a sidetrack into the apex of the cavity. As a successful reentry into the cavity from SR-3A proved to be impossible, the decision was made to drill a new cavity reentry hole.

As of June 31), approximately 65 percent of the salt muck pile (approximately $18,001 \mathrm{cy}$ ) had been crushed and injected into the cavity, which included all of the zone identified by the earlier radiological survey as containing contamination. In addition, approximately 2,000 cy of contamisoil had been excavated and discharged into the cavity. An estimated 9,000 cy of salt remains, of which an estimated $100 \mathrm{cy}$ may contain some contamination. Contaminated soil excavated from beneath the salt muck pile and stozkpiled for disposal is estimated at approximately 2,000 cy.

D. Operational Changes (see attached line diagram)

An evaluation of the remaining cavity space and volumes of salt and soil remaining requires changes in the method of operation. The changes consist of recycling the fluid from the cavity and tunnel complex back to the surface, through a piping system directly to the wellhead of the new reentry well for direct discharge into the hopper and immediately downhole. This measure is required to conserve cavity space for solids. The crushing plant will be reconfigured to eliminate the long run of sloping pipe which previously carried the slurry to the SR-2A wellhead; hence, substantially less recycled fluid will have to be used than the fresh water previously utilized because it will now serve only as a lubricant rather than a transport agent. The fluid to be recycled will be returned to the surface by a pump run in Hole LRL-7 which will discharge into a storage tank at the LRL-7 location. The water will be carried to the new hole, designated Decontamination and Decommissioning Hole No. 1 (DD-1), by gravity flow. The differential elevation from the tank to the wellhead hopper will result in pressures of about $30 \mathrm{psi}$ at the hopper. The line from the tank will be assembled with Victaulic couplings and will have shutoff valves at both the tank end and the discharge end. Plasticlined sumps will be constructed at each Victaulic coupling location. The valve at the discharge end will be a "ball" type which can be shut off in one-fourth turn. The line will be installed so as to have no low point and will drain by gravity. The storage tank shall have a reliable float-actuated switch to assure shutdown of the pump when the fluid in the tank reaches a prescribed level. The pump will be a downhole turbine type set at approximately 1,300 feet and powered by generator.

The hopper at the DD-1 wellhead will be a bottom discharge type shrouded as required to eliminate the problem of fluid splashing out, but also arranged so it can be observed at all times. A close observation of the cavity backpressure as materials are discharged into the cavity is required to prevent a backpressure buildup from causing a bridging of the downhole 
discharge pipe. The system to filter air released from the cavity will be connected to and maintained operational at Hole DD-1. The reconfiguration of the crushing plant units will make it necessary to transport materials a longer distance to the primary crusher unit. Any soil spills that may result can be readily picked up from the surface upon completion of the operation.

In the event the cavity volume is not sufficient to accommodate all of the uncontaminated salt after all of the contaminated soil has been placed in the cavity, approval will be sought to excavate trenches of sufficient depth to contain the salt so that when backfilled to the natural ground surface, vegetation will be reestablished and survive.

A deluge-type shower will be assembled and erected near the DD-1 wellhead so as to provide a method to quickly wash off personnel affected in the event of any splashing or spilling of recycled cavity fluid.

\section{E. Responsibilities}

Al1 downhole slurrying operations prior to June 30, 1979, utilized fresh water pumped from Wel1 USGS No. 1 , which resulted in a limited probability for contamination of personnel. Since the changed method of operation necessitates the recycling of fluid which has passed through the cavity region, additional measures must be taken to assure that care and precaution commensurate with the hazards are enforced.

$\underline{\text { Fenix \& Scission }}$

Fenix \& Scission, with continuing responsibility for the surface plant and downhole slurrying operation, must also assure that the reconfigured plant facility, including all lines and valves, the holding tank, the hopper, and the pump and connecting lines, have been properly installed and tested prior to being charged with recycled fluid so as to avoid any possible leaks and to maintain the integrity of the system throughout its operation. F\&S will also be responsible for the following specific areas as it relates to continuation of the operation:

1. Advise and coordinate with REECo Rad-Safe any planned entries in the fluid recycling system to determine fluid or solid levels or when any leaks of recycled fluids may be discovered, including the disassembly and demobilization of the system.

2. Inspect all water pipelines, valves, and the tank and hopper during the operation so as to detect any leaks at the earliest moment.

3. Drain pipelines at the end of each day's operation so that no fluid is available to leak during nonworking hours.

4. Close and secure all valves so they cannot be opened by unauthorized persons (includes cavity shutoff valves, storage tank valves, and pipeline valves). 
5. Monitor the fluid storage tank in order to assure that the pump shutdown switch is always working properly.

6. Maintain a continuing program for establishing, recording, and evaluating the fluid and solid levels tagged in the cavity and LRL-7 so as to accurately forecast, project, and schedule the balance of the disposal work.

7. Establish and maintain a record of the total materials (salt, sand, soil, and fluid) discharged into the cavity or recycled, and the balance of salt and soil or sand to be disposed of.

$\underline{\text { REECo }}$

REECo, with continuing responsibility for radiological safety operations, will institute the following supplemental procedures:

1. Collect water samples twice a day from the LRL-7 holding tank and analyze them for $\mathrm{H}-3$ and gamma-emitting isotopes. A minimum of one sample per week will be sent to the NTS for further analysis.

2. Analyze any leakage residue detected by F\&S between LRL-7 and DD-1.

3. Maintain a bubbler sample on the injection hole hopper during downhole operations and analyze for tritium.

4. Provide a radiation monitor with portable instruments to monitor any opening of the downhole system during bottom or water tagging operations at SR-2A, DD-1, LRL-7, LRL-8, or other opening/communication with the cavity or tunnels.

5. Collect additional bioassay samples from personnel, as required.

6. Indoctrinate workers by explaining any potential increased risk.

7. Cover all drilling operations in accordance with the sections covering Phase III cleanout of SR-2A and LRL-7. 

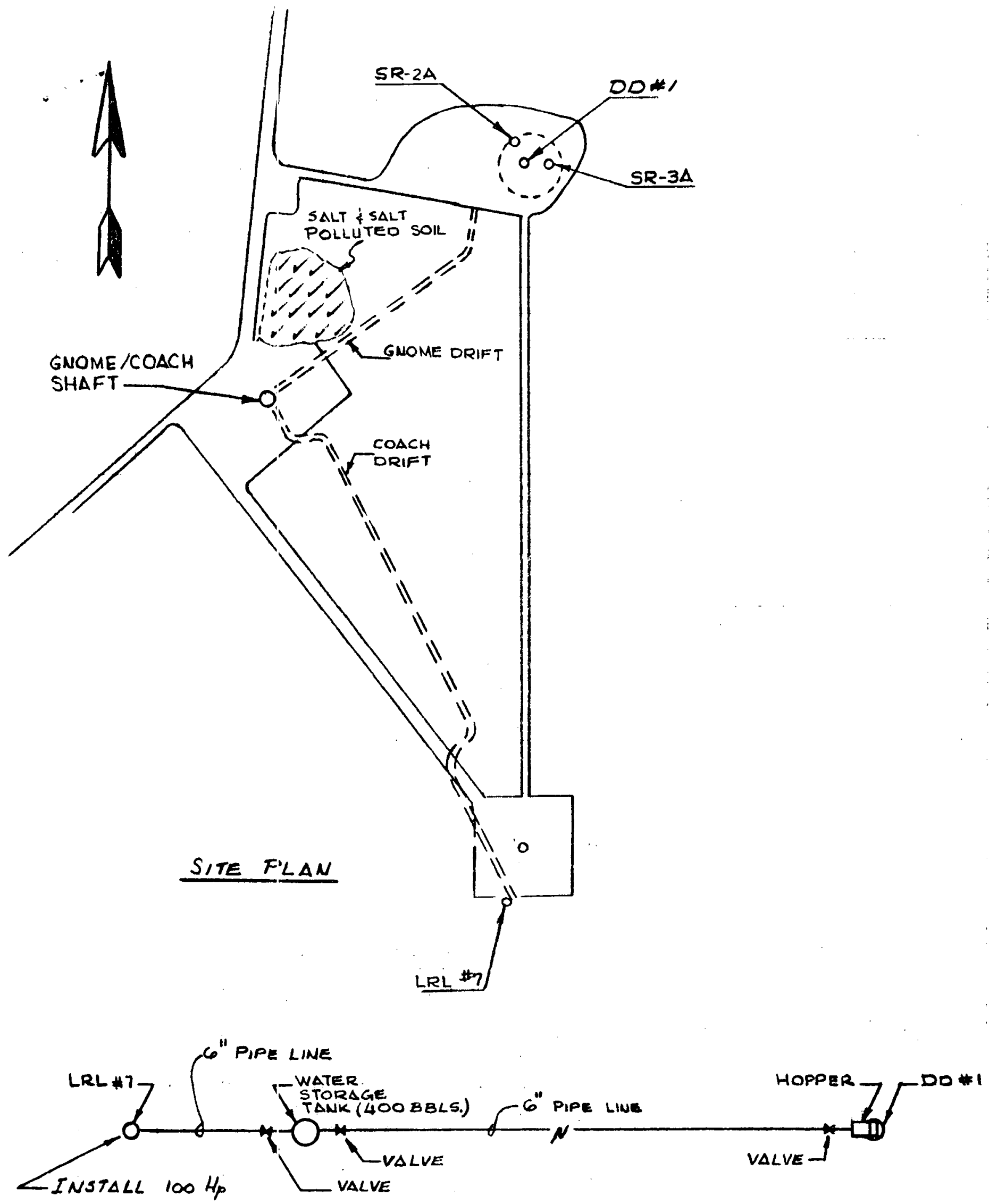

SUB: PUMP

IN LRL \#?

PUMP $\triangle T \approx 1300^{\circ}$

LINE DIAGRAM

$7 / 9 / 79$ 